\title{
Continuous-flow cryocompression therapy penetrates to bone level in hip fracture patients in a numerical simulation
}

\author{
Nick C. Leegwater ${ }^{1 *}$, Sander M. van der Meer $^{2}$, Inger N. Sierevelt ${ }^{1}$, Hugo Spruijt $^{2}$ and Peter A. Nolte ${ }^{1}$
}

\begin{abstract}
Background: The aim of this study was to define deep tissue temperature during cryotherapy in postoperative hip fracture patients, by using measured skin temperature as input parameter for a simple numerical model. Second, an association was investigated between pain and tissue temperature distribution, to assess cryotherapy-induced analgesia of soft tissue-derived pain.
\end{abstract}

Methods: Data from 35 participants in an ongoing trial was used. In three subjects who consented on optional measurements, skin temperature was measured in 3 days during and after cryotherapy. A simple numerical model was developed to calculate tissue temperature distribution during cryotherapy.

Results: Inter and intrasubject skin temperature displayed high variation: trochanter $11-27^{\circ} \mathrm{C}$, mid-femur $11-24^{\circ} \mathrm{C}$, distal femur $10-16^{\circ} \mathrm{C}$. Predicted temperatures decreased to $20^{\circ} \mathrm{C}$ at $1 \mathrm{~cm}, 26^{\circ} \mathrm{C}$ at $2 \mathrm{~cm}$, and $30^{\circ} \mathrm{C}$ at $3 \mathrm{~cm}$ tissue depth. Smallest soft tissue layer was measured at the trochanter; $42 \%$ had less than $30 \mathrm{~mm}$ and $21 \%$ had less than $20 \mathrm{~mm}$. Numeric rating scale pain varied (mean $=2.14 ; \mathrm{SD}=1.92$ ), and no association was found between pain and decrease in temperature $(r=0.064 ; p=0.204)$.

Conclusions: Cryotherapy was predicted to reduce temperature up to $3 \mathrm{~cm}$; in cachectic patients, this reaches the bone, where it might have implications for bone tissue healing when treated for a prolonged period of time. Cryotherapy-induced analgesia is likely to originate from skin analgesia rather than analgesia of muscle or bone-derived pain.

Keywords: Cryotherapy, Hip fracture, Hypothermia, Analgesia, Thermodynamics

\section{Background}

Cryotherapy is used to treat pain after musculoskeletal trauma such as total hip arthroplasty, total knee arthroplasty, and hip fractures [1-4]. Skin temperatures less than $13.6^{\circ} \mathrm{C}$ produce skin analgesia [5]. In ankles, nerve conduction velocity is reduced with $33 \%$ at $10^{\circ} \mathrm{C}$ skin temperature, resulting in a higher pain threshold [6]. Continuous-flow cryocompression therapy (CFCT) reduces skin temperature to $10^{\circ} \mathrm{C}$ and to $22-25^{\circ} \mathrm{C}$ up to $1.5 \mathrm{~cm}$ below the subcutaneous layer in the thighs of healthy individuals $[7,8]$. Hypothermia diminishes the cell's metabolic rate by two to fourfold per $10^{\circ} \mathrm{C}$ drop in

\footnotetext{
* Correspondence: nleegwater@spaarnegasthuis.nl

${ }^{1}$ Department of Orthopedics, Spaarne Gasthuis, Spaarnepoort 1, 2134 TM Hoofddorp, The Netherlands

Full list of author information is available at the end of the article
}

the mammalian central nervous system [9]. Mild hypothermia $\left(28-34^{\circ} \mathrm{C}\right)$ has shown to produce anti-inflammatory effects in healthy subjects [10], but sub-physiologic temperatures of less than $32^{\circ} \mathrm{C}$ are also known to severely decrease proliferation in mammalian cells [11] and halts proliferation completely in mouse embryo fibroblasts [12]. In addition, at $34^{\circ} \mathrm{C}$ hypothermia severely impairs osteoblast activity and doubles osteoclast activity in a calvarial rodent model [13]. Thus, a decrease in skin temperature is advantageous to treat pain, but adversely affects tissue metabolism, fibroblast, osteoblast, and osteoclast function that are needed for repair of soft tissue and bone. Whether cryotherapy reduces the temperature at the bone level after hip fracture surgery, possibly leading to impaired cellular function, is unknown. Furthermore, it is also 
unclear whether cooling of muscle and bone tissue at greater depth contributes to the analgesic effect of cryotherapy.

The aim of this study was to define deep tissue temperature during CFCT in postoperative hip fracture patients, by using measured skin temperature as input parameter for a simple numerical model. Second, an association between tissue temperature distribution and pain was investigated to assess cryotherapy-induced analgesia of soft tissue-derived pain. We hypothesized that (1) soft tissue temperature at the bone level (as determined on X-ray) will decrease during cryotherapy and (2) that temperature decrease and decline in pain perception by hip fracture patients as measured by numeric rating scale (NRS) pain are associated.

\section{Methods}

The Medical Ethical Committee "METC Noord-Holland", Alkmaar, The Netherlands (date: October 13, 2015; reference no: NH015.188) approved amendments in an ongoing trial that enabled additional measurements to be performed for the current study. These amendments also allowed subjects to be able to optionally consent with skin temperature measurements specifically for this study. After obtaining written informed consent, data on demographics, height, weight, implant type, pain scores before and after CFCT, and - if applicable - skin temperature measurements were obtained from subjects that participated in a multi-center trial [3]. All subjects that were allocated to receive CFCT at the Spaarne Gasthuis hospital as part of participation in this multi-center study were selected for data analysis in this study.

Continuous-flow cryocompression therapy was applied by using the "Game Ready System" (GRS; CoolSystems Alameda, California) according to the cryotherapy treatment protocol as published earlier [14]. Through anatomically designed wraps, the GRS simultaneously delivers both adjustable continuous-flow cryotherapy and intermittent compression. The machine can be set at no pressure, low pressure $(5-15 \mathrm{mmHg})$, medium pressure $(5-50 \mathrm{mmHg})$, and high pressure $(5-75 \mathrm{mmHg})$. Temperature can be adjusted between $4{ }^{\circ} \mathrm{C}$ and $13^{\circ} \mathrm{C}$; the lowest temperature was used. Pressure started at "low" and increased per four treatments to "medium" and "high." Twelve treatment cycles were administered four times daily during the first 72 postoperative hours. A sole investigator applied and/or removed the wrap to perform the temperature measurements to reduce measurement variability. Before and after each treatment cycle, the subject was asked to verbalize perceived NRS pain.

In subjects who consented with optional skin temperature measurements, the cooling area was measured with a four-channel thermometer type TM-947SD with thermo probes type T; $12 \mathrm{M}-\mathrm{T}-0.5$ Class 1 (Lutron
Electronic Enterprise Co., Taipei, Taiwan) during and after CFCT on three consecutive evenings. Probes were placed laterally at the major trochanter, mid femur, the distal femur $5 \mathrm{~cm}$ proximal to the upper margin of the patella, and laterally on the contralateral femur. After probe placement, CFCT was administered for $30 \mathrm{~min}$. Upon completion, the wrap was removed, and subjects were covered by normal blankets and remained in bed overnight. Skin temperature was measured every $10 \mathrm{~s}$. For total hip arthroplasty, hemiarthroplasty and dynamic hip screw the mid femur temperature was used as input skin temperature for the model because most soft tissue trauma is present at this level, whereas the proximal skin temperature was used for the intramedullary hip nail since most soft tissue trauma is present at the entry point of the nail.

A simple validated numerical model was used to calculate tissue temperature during CFCT. The model uses a finite difference method to solve a one-dimensional temperature equation with the Crank-Nicolson scheme [15]. In order to solve the equation $\Phi(x, t)$ where $\Phi$ is the temperature, " $x$ " is the skin depth, and " $t$ " is time, the following three boundary conditions were used. First, the temperature at the skin $(x=0)$ equals the aforementioned measured skin temperature data $\left(\Phi(0, t)=T_{\text {meas }}(t)\right)$. Second, the temperature at maximum depth " $L$ " of $10 \mathrm{~cm}$ depth $(x=L)$ equals the measured core temperature of the subject $\left(T_{0}\right)$ before CFCT $\left(\Phi(L, t)=T_{0}\right)$. Finally, the initial temperature of the simulated body was also set to the measured core temperature of the subject before CFCT $\left(\Phi\left(x, t_{0}\right)=T_{0}\right)$. The body mass index (BMI) was calculated to determine the overall body mass. BMI and body fat percentage (BF\%) are correlated, and based on this correlation, $\mathrm{BF} \%$ was calculated and used as input parameter [16]. Assuming the tissue to be a homogeneous fat-water mixture, the thermal diffusivity was linearly interpolated between plain water $\left(0.149 \times 10^{-6} \mathrm{~m}^{2} / \mathrm{s}\right)$ and fat $\left(0.1 \times 10^{-6}\right.$ $\mathrm{m}^{2} / \mathrm{s}$ ), based on the BF\% of the subject. A 1-s temperature resolution during a simulated time of half an hour and a spatial resolution of $0.1 \mathrm{~mm}$ were used.

Soft tissue dimensions were obtained from X-rays of all subjects (Fig. 1). The measurements were calibrated using implants with known dimensions. With the numerical simulation model, the minimum and mean temperature at those depths during CFCT was determined.

\section{Statistics}

Statistical analysis was performed using IBM SPSS Statistics for Windows 25.0 (IBM, Armonk, NY). Both univariate and multivariate analyses were performed to assess the association between temperature distribution after CFCT and treatment effect during the first 72 postoperative hours. Treatment effect was defined as NRS pain improvement, which is defined as pretreatment 


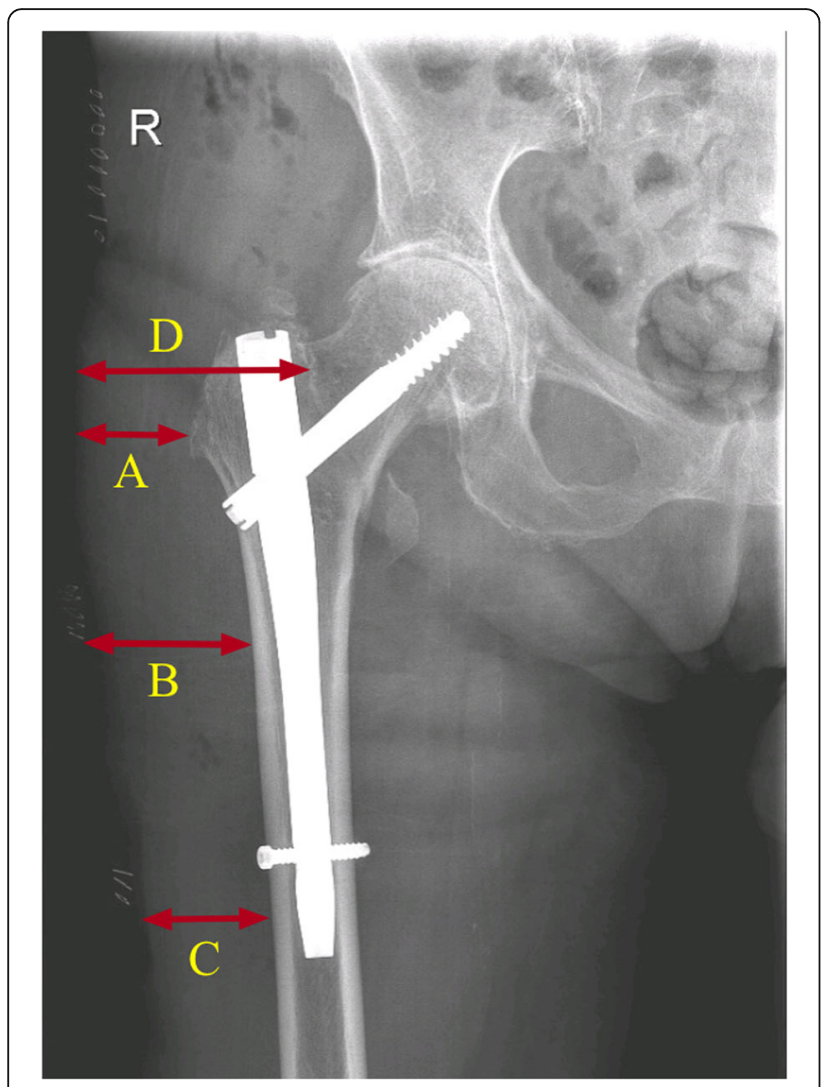

Fig. 1 Tissue dimensions on an X-ray of an intramedullary hip nail for a right-sided peritrochanteric fracture. a Trochanter distance. b Mid femur distance. c Distal femur distance. $\mathbf{d}$ Shortest skin-to-fracture distance

NRS pain minus post-treatment NRS pain. Mixed model repeated measures analysis of covariance was performed and adjusted for potential confounders (gender, BMI, surgery type, fracture type, and pressure settings). Additional analysis was performed to assess the course of NRS pain after treatment during the first $72 \mathrm{~h}$. A $p$ value $<0.05$ was considered statistically significant.

\section{Results}

Data from 35 subjects were selected and eligible for data analysis; characteristics are displayed in Table 1 . In ten subjects, incomplete pain measurements precluded pain analysis. Post-treatment NRS pain declined over the course of treatments during $72 \mathrm{~h}$ with 0.14 NRS per $6 \mathrm{~h}$ from 3.0 to $1.57(p<0.001)$, possibly reflecting reduction in inflammation and/or edema.

Three subjects consented with optional skin temperature measurements. Subjects 1 and 2 had a peritrochanteric fracture and an intramedullary hip nail was implanted, subject 1 was a cachectic male (age 76 years, weight $62 \mathrm{~kg}$, height $182 \mathrm{~cm}$ ), and subject 2 was an obese male (age 93 years, weight $100 \mathrm{~kg}$, height $175 \mathrm{~cm}$ ). Subject 3 was a cachectic female (age 91 years, weight $53 \mathrm{~kg}$, height $150 \mathrm{~cm}$ )
Table 1 Subject characteristics

\begin{tabular}{ll}
\hline Variable & $\begin{array}{l}\text { Cryotherapy subjects } \\
(n=35)\end{array}$ \\
\hline Female, $n$ & 26 \\
Age, years & $80.5(40-95)$ \\
Weight, kg & $66(48-106)$ \\
Height, cm & $168(150-192)$ \\
BMI, kg/m² & $22(20-34)$ \\
Type of surgery, $n$ & \\
DHS & 9 \\
HATHA & 12 \\
IMHN & 14 \\
\hline
\end{tabular}

Data are reported as median and range unless stated otherwise $B M I$ body mass index, DHS dynamic hip screw, HA hemiarthroplasty, THA total hip arthroplasty, IMHN intramedullary hip nail

with a medial column fracture where a hemiarthroplasty was performed. In subject 1 , only two registrations were obtained, and in one registration, two probes had a technical failure. In one registration, the distal temperature probe registered a minimum temperature of $30.8{ }^{\circ} \mathrm{C}$, which was considered an error (probe was not covered by the wrap) and was omitted (Table 2). Inter and intrasubject skin temperature varied greatly. In subject 2, the highpressure setting resulted in the lowest skin temperature measured, while in subject 3, the high-pressure setting did not result in a decrease in skin temperature. In all cases, the fastest decrease in skin temperature occurred the first 5 minutes of CFCT, and the minimum temperature reached was $11.5^{\circ} \mathrm{C}$ at mid-femur after $27 \mathrm{~min}$ (Fig. 2). After cessation of CFCT, it took $5.5 \mathrm{~min}$ before the temperature exceeded $13.6{ }^{\circ} \mathrm{C}$ (the threshold that produces skin analgesia), and after $179 \mathrm{~min}$ (SD 52.7) baseline temperature was reached (Fig. 2). No reactive hyperthermia was observed after cessation of CFCT (Fig. 2).

The initial measured skin temperature dropped on average from $32.1{ }^{\circ} \mathrm{C}$ to $18.2^{\circ} \mathrm{C}$ after $30 \mathrm{~min}$ of CFCT. Consequently, in model simulations during CFCT (also up to $30 \mathrm{~min}$ ), the average temperature dropped to $24.1{ }^{\circ} \mathrm{C}$ at $1 \mathrm{~cm}$ tissue depth, $28.1^{\circ} \mathrm{C}$ at $2 \mathrm{~cm}$ tissue depth, and $30.4{ }^{\circ} \mathrm{C}$ at $3 \mathrm{~cm}$ tissue depth (Fig. 3). Temperature slightly dropped at $3 \mathrm{~cm}$ tissue depth and remained unaffected at deeper levels (Fig. 3). Soft tissue dimensions were acquired from postoperative X-rays in 24 subjects; in four subjects, no postoperative $\mathrm{X}$-rays were taken; and in seven subjects, insufficient $\mathrm{X}$-ray quality (soft-tissue reached outside the X-ray image) precluded measurements. Forty-two percent had a skin-to-bone distance of less than $30 \mathrm{~mm}$, and $21 \%$ had a distance of $20 \mathrm{~mm}$ or less, the smallest usually being the trochanter (Fig. 1, arrow A). The lowest temperatures were observed at the trochanter and the distal femur (Table 3). 
Table 2 Skin temperature measurements during cryotherapy treatment

\begin{tabular}{|c|c|c|c|c|c|c|c|c|c|c|c|}
\hline \multirow{3}{*}{$\begin{array}{l}\text { Subject } \\
\text { no. }\end{array}$} & \multirow[t]{3}{*}{ BMl } & \multirow[t]{3}{*}{ Timing } & \multirow[t]{3}{*}{ Pressure } & \multirow{2}{*}{\multicolumn{2}{|c|}{ NRS }} & \multirow{2}{*}{\multicolumn{2}{|c|}{$\begin{array}{l}\text { Core temp. } \\
\left({ }^{\circ} \mathrm{C}\right)^{\ddagger}\end{array}$}} & \multicolumn{4}{|c|}{ Minimal skin temperature $\left({ }^{\circ} \mathrm{C}\right)$} \\
\hline & & & & & & & & \multirow[t]{2}{*}{ Trochanter } & \multirow{2}{*}{$\begin{array}{l}\text { Mid } \\
\text { femur }\end{array}$} & \multirow{2}{*}{$\begin{array}{l}\text { Distal } \\
\text { femur }\end{array}$} & \multirow[t]{2}{*}{ Contralateral } \\
\hline & & & & Pre & Post & Pre & Post & & & & \\
\hline \multirow[t]{3}{*}{1} & \multirow[t]{3}{*}{18.7} & POD 1 & Low & - & - & - & - & - & - & - & - \\
\hline & & POD 2 & High $^{*}$ & 3 & 0 & 37.1 & 37.1 & 21 & - & - & 34 \\
\hline & & POD 3 & High & 1 & 1 & 36.3 & 37.0 & 18 & 11.5 & 14 & 36 \\
\hline \multirow[t]{3}{*}{2} & \multirow[t]{3}{*}{32.6} & POD 1 & Low & 3 & 3 & 37.0 & 36.6 & 27 & 20 & 16 & 34.5 \\
\hline & & POD 2 & Medium & 8 & 5 & 37.2 & 37.2 & 12 & 19 & 16 & 34 \\
\hline & & POD 3 & High & 3 & 3 & 36.6 & 36.6 & 10.5 & 20.5 & 31 & 34 \\
\hline \multirow[t]{3}{*}{3} & \multirow[t]{3}{*}{23.6} & POD 1 & Low & 0 & 0 & 38.7 & 36.5 & 13 & 18.5 & 10 & 31 \\
\hline & & POD 2 & Medium & 0 & 0 & 38.3 & 37.9 & 24 & 24 & 15 & 33.5 \\
\hline & & POD 3 & High & 0 & 0 & 37.8 & 36.9 & 26 & 11.5 & 14.5 & 34.5 \\
\hline
\end{tabular}

$P O D$ postoperative day, NRS numeric rating scale, $0-10$

*Pressure was incorrectly set to high-pressure at day 2

${ }^{\ddagger}$ Auricular measurement

No association was found between NRS pain and tissue temperature distribution at the central soft tissue (adjusted $\beta$ coefficient $0.03(-0.24 ; 0.31) p=0.81)$ ).

\section{Discussion}

Cryotherapy is used to alleviate pain and to reduce inflammation after musculoskeletal trauma [2, 17], but hypothermia might not always be beneficial for various cell types that are required for soft tissue and bone healing. It is important to understand to which depth CFCT reduces the temperature in order to put the effects on cellular function that are already known into perspective. Also, a correlation between tissue temperature distribution and pain perception might help to address the knowledge gap whether cooling of muscle and bone tissue at greater depth contributes to the analgesic effect of cryotherapy.

This is the first study attempting to define CFCT-induced deep tissue temperature drop and to correlate this decline with a change in pain in postoperative hip fracture patients. We found the minimum skin temperature to drop to $10-11^{\circ} \mathrm{C}$ by cryotherapy. These observations are in line with others who measured a temperature of $12^{\circ} \mathrm{C}$ on the skin at the distal thigh of healthy individuals with the same cryotherapy machine that was used in the current study [7]. Skin temperature

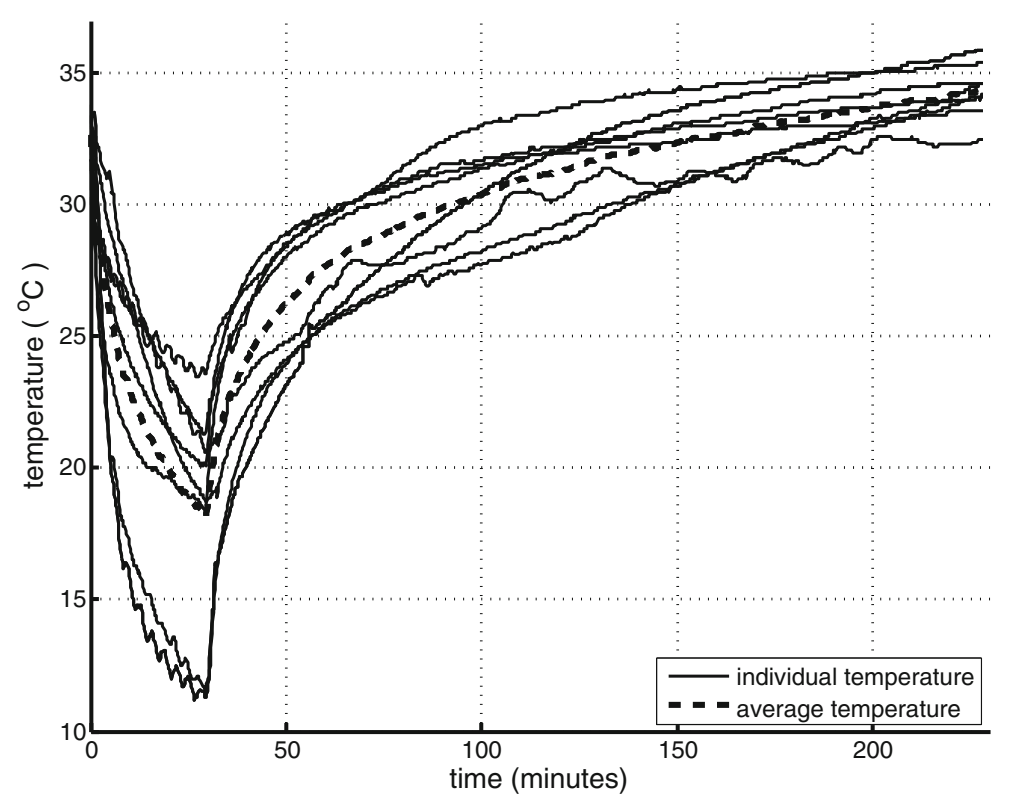

Fig. 2 The average and individual temperature drop during 30 min of continuous-flow cryocompression therapy and subsequent passive rewarming measured at mid-femur 


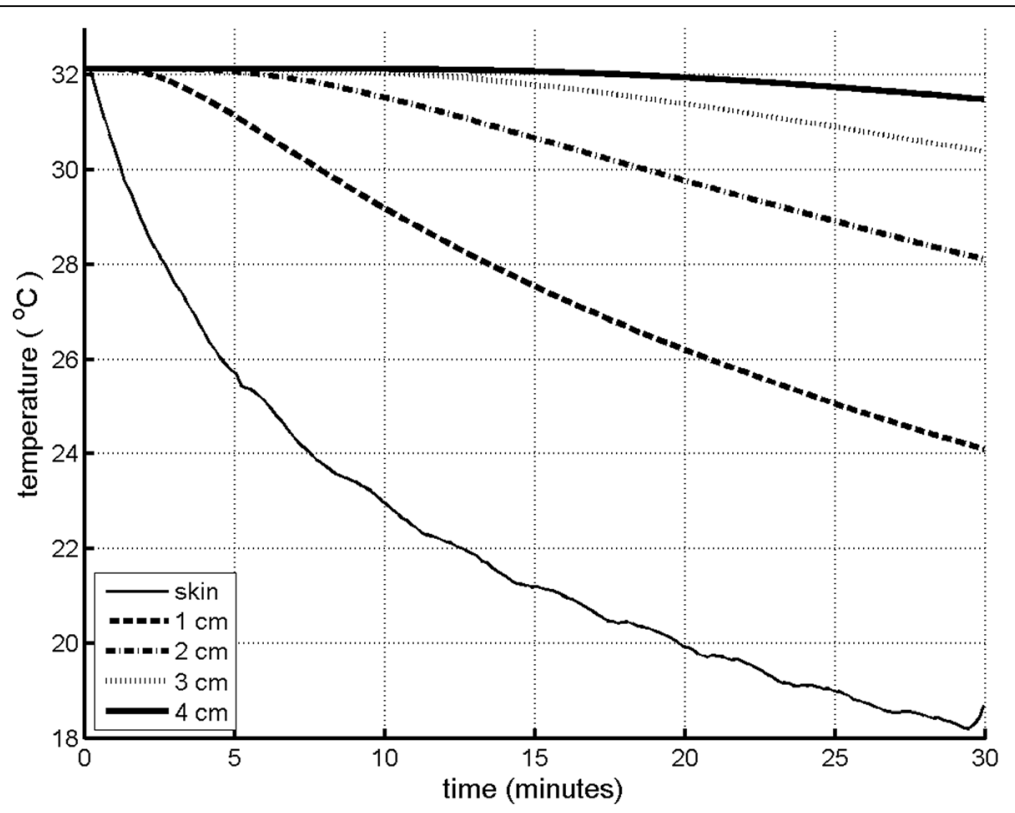

Fig. 3 The average calculated temperature distribution during continuous-flow cryocompression therapy at various tissue depths

drops to $10^{\circ} \mathrm{C}$ when an ice pack or when a $4: 1$ water-alcohol (70\%) mixture is applied [18]. The pressure setting did not affect cooling efficacy at the skin level in our obese subject, but it did augment cooling in our cachectic subject. In both ice-bag treatment and CFCT, external compression augments cooling efficacy $[7,8]$. Although dynamic compression increases CFCT's efficacy, it does not surpass the more traditional solid-state ice application modalities in skin temperature reduction. Heterogeneity in the application of the wrap can be an explanation for the varying skin temperatures. In addition, subjects with excess fat around the hips form the upper leg in a cone-like shape. This shape may cause difficulty in properly conforming the wrap to the thigh; the wrap usually covers most of the upper leg, whereas solid-state ice bags are applied directly to the target area.

In accordance with others [7, 8], in our model calculations, temperature dropped to $23^{\circ} \mathrm{C}$ at $1.5 \mathrm{~cm}$ and to $26^{\circ} \mathrm{C}$ at $2 \mathrm{~cm}$ tissue depth. Ice bag treatment combined with an elastic wrap reduces temperature to $25^{\circ} \mathrm{C}$ at $2 \mathrm{~cm}$ in $30 \mathrm{~min}$ [8], whereas the cryotherapy device that was used in the current study reduces soft tissue to $23^{\circ} \mathrm{C}$ at $1.5 \mathrm{~cm}$ depth at the high-pressure setting [7]. We found no reports on temperature drop at deeper levels. In our model, a temperature drop from $32.1{ }^{\circ} \mathrm{C}$ to $30.4{ }^{\circ} \mathrm{C}$ at $3 \mathrm{~cm}$ was the deepest level where a significant drop in temperature was calculated. Forty-two percent of the subjects had a skin-to-bone distance of less than $30 \mathrm{~mm}$, and $21 \%$ had a distance of $20 \mathrm{~mm}$ or less at the major trochanter. This suggests that CFCT not only reduces soft tissue temperature but might also reduce bone temperature in hip fracture patients that have less than $30 \mathrm{~mm}$ of soft tissue. Temperatures such as $25-30^{\circ} \mathrm{C}$ may retard connective tissue healing since proliferation is severely decreased [11], and proliferation halted in mouse embryo fibroblasts at $32^{\circ} \mathrm{C}$ [12]. It might also have implications for bone healing, as osteoblast activity is severely impaired and osteoclast activity promoted in murine calvarial cells subjected to $34^{\circ} \mathrm{C}$ [13]. We previously determined that hypothermia reduces vascular endothelial growth factor 165 (VEGF-165) protein expression under hypoxia, but we did not find the osteogenic differentiation of

Table 3 Calculated deep soft tissue temperature after cryotherapy treatment

\begin{tabular}{|c|c|c|c|c|}
\hline \multirow[t]{2}{*}{ Dimension } & \multirow{2}{*}{$\begin{array}{l}\text { X-ray* } \\
(\mathrm{mm})\end{array}$} & \multicolumn{3}{|c|}{ Simulated temperature $\left({ }^{\circ} \mathrm{C}\right)$ at $\mathrm{X}$-ray distance } \\
\hline & & Minimal & Average & Maximal \\
\hline A-Trochanter & $34.1(13.8)$ & $27.1(2.7)$ & $30.1(1.9)$ & $31.9(1.3)$ \\
\hline B-Central & $42.6(13.6)$ & $31.7(1.7)$ & $32.5(1.1)$ & $33.0(0.7)$ \\
\hline C-Distal & $37.6(11.6)$ & $31.0(2.0)$ & $32.0(1.3)$ & $32.8(0.8)$ \\
\hline D_Fracture distance ${ }^{A}$ & $59.6(10.8)$ & $32.8(2.1)$ & $33.1(1.3)$ & $33.3(0.8)$ \\
\hline
\end{tabular}

Data are reported as mean and standard deviation

*Skin distance based on first postoperative X-ray from 24 subjects

${ }^{A}$ The shortest distance measured from skin to the center of the fracture or the lateral confinement of the prosthesis in THA/HA subjects 
human adipose stem cells to be impaired [19]. Since the CFCT treatments in our study were applied intermittently for $30 \mathrm{~min}$, the temperature drop is short-lived. However, if applied continuously and prolonged, CFCT might adversely affect connective and bone tissue healing.

Continuous-flow cryocompression therapy reduces pain in subjects that completed the 3-day treatment schedule [3]. In the current study, we attempted to determine an association between a predicted tissue temperature drop and a decline in NRS. However, we found no association between tissue temperature and pain perception. Two pathways can be proposed on how cryotherapy exerts its analgesic efficacy, either deeply via an interaction with tissue metabolism and immunomodulation or superficially via an interaction on nerve conduction. After induced soft tissue trauma, cryotherapy restores microcirculatory hemodynamics in rats [17]. Cryotherapy increases the level of anti-inflammatory cytokines IL- 6 and IL-10, which are related to pain [20, 21 and decreases the pro-inflammatory Il- $1 \alpha$ cytokine level in humans [10]. Regarding the superficial pathway, others determined skin temperatures of less than $13.6^{\circ} \mathrm{C}$ to produce skin analgesia [5] and demonstrated reduced nerve conduction velocity due to decreased skin temperature [6]. The reduced nerve conduction velocity correlated with an increase in pain threshold, which was measured with a pressure algometer in the ankles of healthy subjects [6]. Objectively and reliably assessing patient-reported pain perception remains difficult; hence, standardized pain assessment methods are used. However, results obtained by these methods are difficult to translate to the clinical setting. It is questionable if this increase in pain threshold that is measured on the skin indeed provides a clinical noticeable analgesic effect in a postoperative setting, since postoperative pain originates from more than only skin trauma. In our subjects, skin temperature dropped below $13.6{ }^{\circ} \mathrm{C}$, which should produce skin analgesia $[5,6]$ and the reduction of 1.5 NRS pain observed earlier [3] might illustrate this. However, the high variation in NRS pain and skin temperature we measured does hamper firm conclusions about whether the remaining pain originates from muscular tissue or the bone.

Some carefulness has to be taken when interpreting our findings. We did not measure skin folds although subjects with greater skinfold thickness required longer cryotherapy application time in order to produce similar tissue temperature changes [22]. Instead, we calculated the BF\% from the BMI. The skin distances on the X-rays that were used in the model are static, and although edema or hematoma is not likely to dissipate within the first $72 \mathrm{~h}$, it might be influenced by CFCT. Our model uses flat plate geometry; the simulated temperature drop at deeper distances will be underestimated. In reality, on the other hand, even though the therapy applies an external pressure to the tissue, the tissue will be perfused with a constant supply of warm blood. As this is not incorporated in the model, the model overestimates the temperature decrease. However, these effects act in opposite direction. With our simulation, we also found similar temperature and a similar penetration depths of $2-3 \mathrm{~cm}$ during $30 \mathrm{~min}$ CFCT, which matches to temperatures and penetration depths found in the literature $[7,8]$. This suggests the simple model is adequate for our research questions.

\section{Conclusions}

In our numerical simulation, we predicted cryotherapy to reduce temperature to approximately $3-\mathrm{cm}$ tissue depth; in cachectic patients, this reaches the bone, where it might have implications for bone tissue healing when treated for a prolonged period of time. The lack of a correlation between pain and predicted decrease in temperature might implicate that cryotherapy-induced analgesia is likely to originate from skin analgesia rather than analgesia of muscle or bone-derived pain.

\section{Abbreviations \\ BF\%: Body fat percentage; BMl: Body mass index; CFCT: Continuous-flow cryocompression therapy; GRS: Game Ready System; NRS: Numeric rating scale; VEGF: Vascular endothelial growth factor \\ Acknowledgements \\ None. \\ Funding \\ The cryocompression devices were sponsored by Best Medical Recovery systems (Abcoude, The Netherlands) and were returned after the study ended. 'Achmea Zorgverzekeringen' (grant number: Z557) and 'DSW Zorgverzekeringen' (grant identifier: GRAPES) funded the study. The funding covered meetings, IRB application costs and CFCT treatment by nurses. None of the authors received funding from the study.}

\section{Availability of data and materials}

The datasets used and/or analysed during the current study are available from the corresponding author on reasonable request.

\section{Authors' contributions}

$\mathrm{NL}, \mathrm{SM}, \mathrm{HS}$, and PN contributed to the study design. NL contributed to the acquisition of data. IS and SM contributed to the data analyses. IS and SM contributed to the statistical analysis. NL, SM, and IS contributed to the interpretation of the data. NL and SM contributed to the drafting of the article. NL, SM, IS, HS, and PN contributed to the critical revising for important intellectual content. All authors read and approved the final manuscript.

\section{Ethics approval and consent to participate}

The Medical Ethical Committee 'METC Noord-Holland', Alkmaar, The Netherlands (date: October 13, 2015; reference no: NH015.188) approved amendments in an ongoing trial [3] that enabled additional measurements to be performed for the current study. After obtaining written informed consent, data from a subset of 35 subjects was obtained.

Consent for publication

Not applicable.

Competing interests

The authors declare that they have no competing interests. 


\section{Publisher's Note}

Springer Nature remains neutral with regard to jurisdictional claims in published maps and institutional affiliations.

\section{Author details}

'Department of Orthopedics, Spaarne Gasthuis, Spaarnepoort 1, 2134 TM Hoofddorp, The Netherlands. ${ }^{2}$ Department of Clinical Physics, Spaarne Gasthuis, Hoofddorp, The Netherlands.

Received: 27 July 2018 Accepted: 31 January 2019

Published online: 14 February 2019

\section{References}

1. Adie S, Naylor JM, Harris I. Cryotherapy after total knee arthroplasty a systematic review and meta-analysis of randomized controlled trials. J Arthroplasty. 2010;25:709-15. https://doi.org/10.1016/j.arth.2009.07.010.

2. Song $M$, Sun $X$, Tian $X$, et al. Compressive cryotherapy versus cryotherapy alone in patients undergoing knee surgery: a meta-analysis. Springerplus. 2016;5:1-12. https://doi.org/10.1186/s40064-016-2690-7.

3. Leegwater NC, Bloemers FW, de Korte N, et al. Postoperative continuousflow cryocompression therapy in the acute recovery phase of hip fracture surgery-a randomized controlled clinical trial. Injury. 2017;48(12):2754-61. https://doi.org/10.1016/j.injury.2017.10.024.

4. Leegwater NC, Sierevelt I, Nolte PA. The efficacy of continuous-flow cryotherapy machines in the acute recovery phase after lower extremity surgery - a systematic review with meta-analysis of randomized controlled trials. OA Orthop. 2014;2:9.

5. Bugaj R. The cooling, analgesic, and rewarming effects of ice massage on localized skin. Phys Ther. 1975;55:11-9.

6. A a A, George KP. The effect of cryotherapy on nerve conduction velocity, pain threshold and pain tolerance. Br J Sports Med. 2007;41:365-9; discussion 369. https://doi.org/10.1136/bjsm.2006.031237.

7. Holwerda SW, C a T, Womochel KS, Keller DM. Effects of cold modality application with static and intermittent pneumatic compression on tissue temperature and systemic cardiovascular responses. Sports Health. 2013;5: 27-33. https://doi.org/10.1177/1941738112450863.

8. Tomchuk D, Rubley MD, Holcomb WR, et al. The magnitude of tissue cooling during cryotherapy with varied types of compression. J Athl Train. 2010;45:230-7. https://doi.org/10.4085/1062-6050-45.3.230.

9. Erecinska M, Thoresen M, I a S. Effects of hypothermia on energy metabolism in mammalian central nervous system. J Cereb Blood Flow Metab. 2003;23:513-30. https://doi.org/10.1097/01.WCB.0000066287. 21705.21.

10. Lubkowska A, Szyguła Z, Chlubek D, Banfi G. The effect of prolonged wholebody cryostimulation treatment with different amounts of sessions on chosen pro- and anti-inflammatory cytokines levels in healthy men. Scand J Clin Lab Invest. 2011;71:419-25. https://doi.org/10.3109/00365513.2011. 580859 .

11. Fujita J. Cold shock response in mammalian cells. J Mol Microbiol Biotechnol. 1999;1:243-55.

12. Wilke B, Weiner RD. Postoperative cryotherapy: risks versus benefits of continuous-flow cryotherapy units. Clin Podiatr Med Surg. 2003;20:307-22. https://doi.org/10.1016/50891-8422(03)00009-0.

13. Patel JJ, Utting JC, Key ML, et al. Hypothermia inhibits osteoblast differentiation and bone formation but stimulates osteoclastogenesis. Exp Cell Res. 2012;318:2237-44. https://doi.org/10.1016/j.yexcr.2012.06.021.

14. Leegwater NC, Nolte PA, de Korte N, et al (2016) The efficacy of continuousflow cryo and cyclic compression therapy after hip fracture surgery on postoperative pain: design of a prospective, open-label, parallel, multicenter, randomized controlled, clinical trial. BMC Musculoskelet Disord 17:153 . doi: https://doi.org/10.1186/s12891-016-1000-4.

15. Recktenwald GW. Finite-difference approximations to the heat equation. Mech Eng. 2004;0:1-27.

16. Camhi SM, Bray GA, Bouchard C, et al. The relationship of waist circumference and BMI to visceral, subcutaneous, and total body fat: sex and race differences. Obesity. 2011;19:402-8. https://doi.org/10.1038/oby 2010.248 .

17. Schaser K-D, Stover JF, Melcher I, et al. Local cooling restores microcirculatory hemodynamics after closed soft-tissue trauma in rats. J Trauma. 2006;61:642-9. https://doi.org/10.1097/01.ta.0000174922.08781.2f.
18. Kanlayanaphotporn R, Janwantanakul P. Comparison of skin surface temperature during the application of various cryotherapy modalities. Arch Phys Med Rehabil. 2005;86:1411-5. https://doi.org/10.1016/j.apmr. 2004.11.034.

19. Leegwater NC, Bakker AD, Hogervorst JMA, et al. Hypothermia reduces VEGF-165 expression, but not osteogenic differentiation of human adipose stem cells under hypoxia. PLoS One. 2017;12:e0171492. https://doi.org/10. 1371/journal.pone.0171492.

20. Alvarez P, Bogen O, Green PG, Levine JD (2017) Nociceptor interleukin 10 receptor 1 is critical for muscle analgesia induced by repeated bouts of eccentric exercise in the rat. 0: . doi: https://doi.org/10.1097/j.pain. 0000000000000936.

21. Zhou Y-Q, Liu Z, Liu Z-H, et al. Interleukin-6: an emerging regulator of pathological pain. J Neuroinflammation. 2016;13:141. https://doi.org/10. 1186/s12974-016-0607-6.

22. Otte JW, Merrick MA, Ingersoll CD, Cordova ML. Subcutaneous adipose tissue thickness alters cooling time during cryotherapy. Arch Phys Med Rehabil. 2002;83:1501-5. https://doi.org/10.1053/apmr.2002.34833.

\section{Ready to submit your research? Choose BMC and benefit from:}

- fast, convenient online submission

- thorough peer review by experienced researchers in your field

- rapid publication on acceptance

- support for research data, including large and complex data types

- gold Open Access which fosters wider collaboration and increased citations

- maximum visibility for your research: over $100 \mathrm{M}$ website views per year

At BMC, research is always in progress.

Learn more biomedcentral.com/submissions 